\title{
Production and characterization of exocellular proteases in ectomycorrhizal fungi
}

\author{
K. El-Badaoui and B. Botton
}

Université de Nancy I, Faculté des Sciences, Laboratoire de Physiologie Végétale et Forestière, BP 239, 54506 Vandœuvre-lès-Nancy Cedex, France

\section{Introduction}

Mycorrhizas grow very often in soil layers in which organic nitrogen compounds are present in large quantities. The ability of several ectomycorrhizal fungi to assimilate proteins and to transfer their nitrogen to plants has already been demonstrated (Abuzinadah and Read, 1986; Abuzinadah et al., 1986). These results suggest that proteases are excreted by the fungi and protease activities detected in mycorrhizaforming fungi were reported by Lyr (1963) and Ramstedt and Söderhall (1983). In this study, the process of production of exocellular proteases has been investigated in free living fungi as well as in mycorrhizas. Experiments were carried out with Amanita rubescens and Lactarius subdulcis which live in organic horizons and with Cenococcum geophilum and Hebeloma crustuliniforme which live predominantly in mineral soil layers.

\section{Materials and Methods}

The fungi were collected from mycorrhizas. They were grown in shaken cultures at $25^{\circ} \mathrm{C}$ in Pachlewski's medium containing nitrogen as either diammonium tartrate or proteins: bovine serum albumin (BSA), gelatin, casein or proteins extracted from the litter (Botton et al., 1986). Enzyme activities were determined in culture filtrates, either by spectrophotometry or by spectrofluorcmetry using fluorescein isothiocyanate-labeled BSA (FITC-BSA) as described by Twining (1934). Proteins purified from the litter by ammonium sulfate fractionation and DEAE-cellulose chromatography were also labeled with FITC and used as a substrate and as inducers.

\section{Results}

Protease activity remained at a very low level when the fungus was cultivated in the presence of ammonium, but increased strongly after transfer of the organism to fresh medium containing casein, gelatin or BSA as the sole nitrogen source. Gelatin proved to be the most efficient inducer (Fig. 1a). Elimination of carbon, inorganic nitrogen or sulfur was not sufficient to induce exocellular proteases, proteins also had to be present. However, in nitrogen- and carbon-deficient media, gelatin was not efficient (not shown). A group of proteins of about $46 \mathrm{kDa}$ was purified from the forest litter and was a better inducer than gelatin, in spite of its lower concentration, both in $C$. geophilum and $\mathrm{H}$. crustuliniforme (Fig. $1 \mathrm{~b}$ ). 

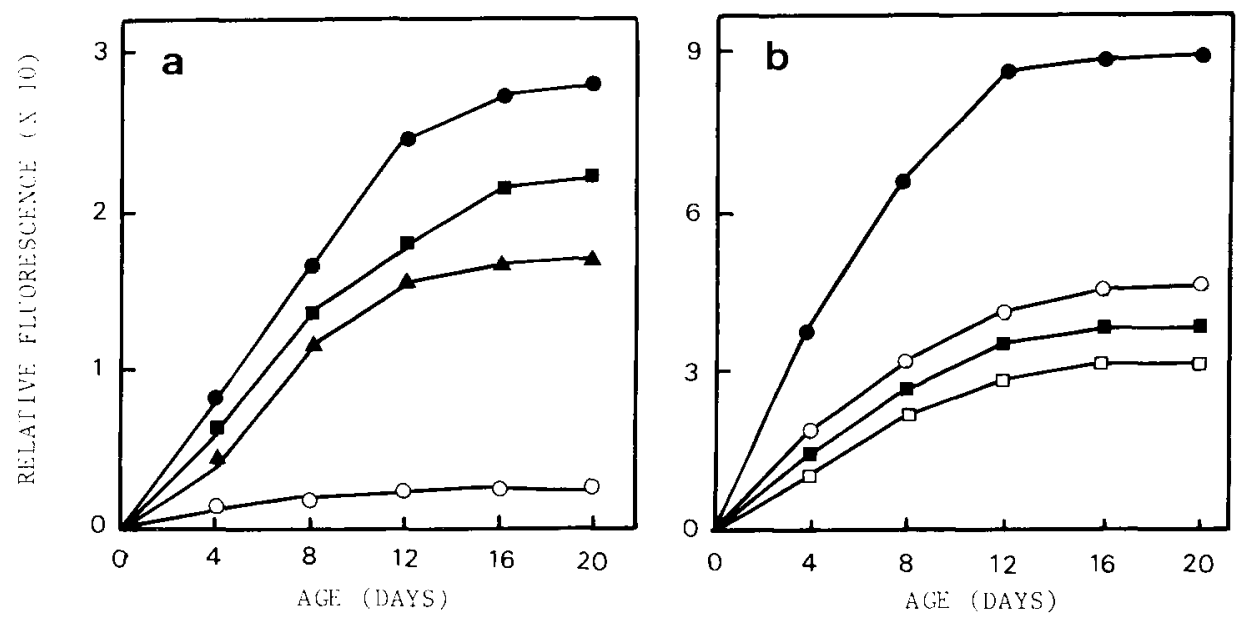

Fig. 1. Induction of protease activities in ectomycorrhizal fungi. a. After transfer of $C$. geophilum to medium containing casein (4), gelatin (O) or BSA (C). The control was transferred onto ammonia-containing medium (O) b. C. geophilum induced by $0.2 \%$ gelatin $(\mathrm{D})$ and by $0.1 \%$ proteins extracted from the litter (U). $H$. crustuliniforme induced by $0.2 \%$ gelatin (O) and by $0.1 \%$ proteins extracted from the litter (O).

As shown in Table I, A. rubescens and L. subdulcis secreted larger amounts of exocellular proteases than $C$. geophilum and $H$. crustuliniforme, although growth of the 2 former fungi was considerably reduced. For the 4 fungi tested, controls with ammonium (Pachlewski's medium) were better developed than the cultures grown in the presence of proteins from the litter, but protease excretion was reduced.

Protease activity was also induced in beech-Lactarius ectomycorrhizas incubated in the presence of litter proteins. Gelatin was less efficient and ammonium repressed the excretion after $48 \mathrm{~h}$ of incubation. Non-mycorrhizal roots did not exhibit protease activity (Fig. 2).

\section{Conclusion}

These results indicate that ectomycorrhizal fungi secrete significant amounts of proteases when the culture medium is
Table I. Protease induction and growth of 4 ectomycorrhizal fungi cultivated in the presence of $0.1 \%$ proteins from the litter (induced) or in the presence of ammonium (Pachlewski's medium).

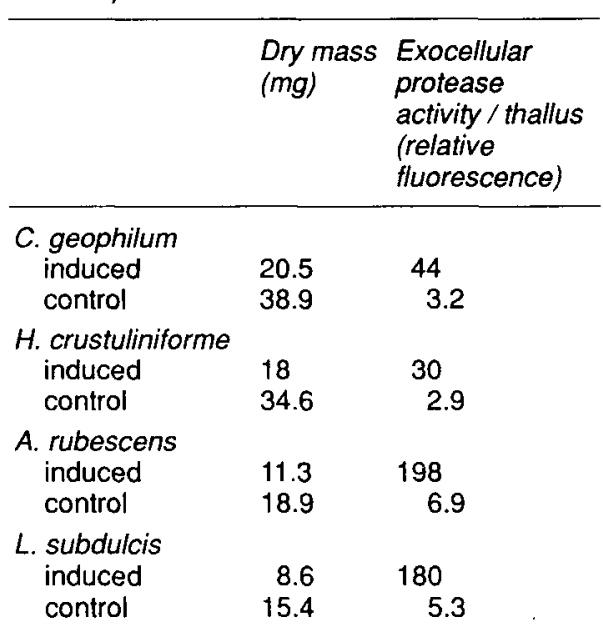

supplemented with proteins. Very often, alkaline proteases were detected in the medium; however, when the fungi were 


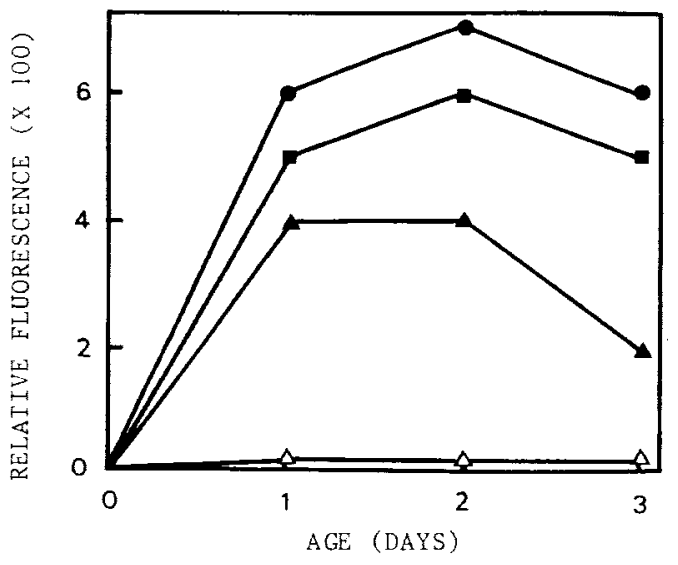

Fig. 2. Protease activity of beech-Lactarius ectomycorrhizas. Mycorrhizas incubated in Pachlewski's medium (A), in $\mathrm{NH}_{4}^{+}$-deficient medium supplemented with gelatin (U), in $\mathrm{NH}_{4}^{+}$-deficient medium supplemented with proteins purified from the litter (O); nonmycorrhizal roots incubated in $\mathrm{NH}_{4}^{+}$-deficient medium supplemented with proteins purified from the litter $(\Delta)$. Proteins from the litter were used as a substrate to determine protease activities.

induced with proteins from the litter and proteases were assayed with the same substrate, optimum $\mathrm{pH}$ of activity was about 5. It is likely that the proteases excreted enable the organism to use extracellular proteins as a source of nitrogen and a close correlation exists between the ability of the fungi to produce such enzymes and their distribution in the soil layers.

\section{References}

Abuzinadah R.A. \& Read D. (1986) The role of proteins in the nitrogen nutrition of ectomycorrhizal plants. 1. Utilization of peptides and proteins by ectomycorrhizal fungi. New Phytol. $103,481-493$

Abuzinadah R.A., Finlay R.D. \& Read D.J. (1986) The role of proteins in the nitrogen nutrition of ectomycorrhizal plants. II. Utilization of proteins by mycorrhizal plants of Pinus contorta. New Phytol. 103, 495-506

Botton B., El-Badaoui K. \& Martin F. (1986) Induction of extracellular proteases in the ascomycete Cenococcum geophilum. In: Physiological and Genetical Aspects of Mycorrhizae. Proceedings of the 1st European Symposium on Mycorrhizae, Dijon, July 1985. INRA, Paris, pp. 403-406

Lyr H. (1963) Mykorrhiza. In: Internationales Mykorrhizazymposium. Jena, 1963. Fisher, Verlag, pp. 123-145

Ramstedt M. \& Söderhall K. (1983) Protease, phenoloxidase and pectinase activities in mycorrhizal fungi. Trans. Br. Mycol. Soc. 81, 157-161

Twining S.S. (1984) Fluorescein isothiocyanatelabeled casein assay for proteolytic enzymes. Anal. Biochem. 143, 30-34 